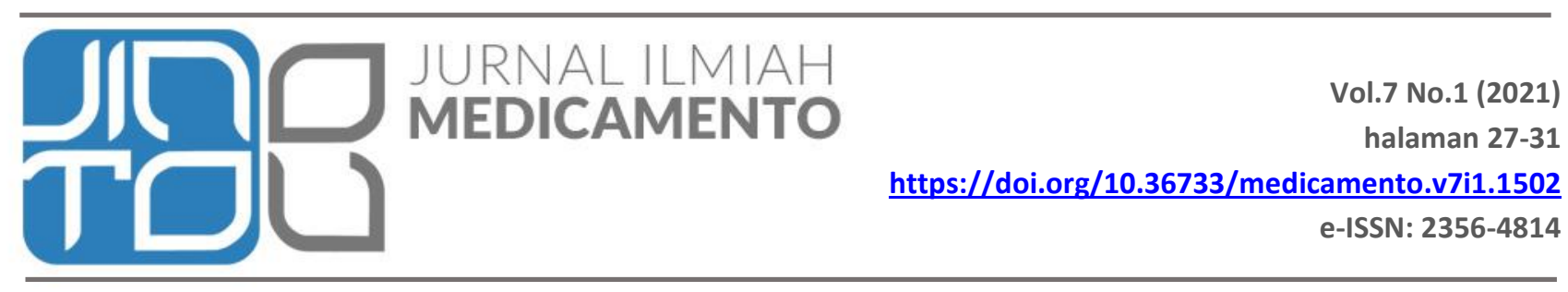

\title{
Uji Aktivitas Analgesik Gel Bulung Boni (Caulerpa Sp.) terhadap Mencit Putih (Mus musculus)
}

\section{Analgesic Test Activity of Boni Seaweed (Caulerpa Sp.) Against White Mice (Mus musculus)}

\author{
Ni Luh Putu Erika Putri Jayantini' ${ }^{1 \bullet}$, Ni Putu Trisna Ayundita ${ }^{1}$, I Putu Aditya Mahaputra ${ }^{1}$, \\ Firlyandhika Dwi Fatturochman ${ }^{1}$, Anak Agung Gede Rai Yadnya Putra ${ }^{1}$ \\ 1 Program Studi Farmasi, Fakultas Matematika dan Ilmu Pengetahuan Alam, Universitas Udayna, Denpasar, Bali, Indonesia
}

\begin{abstract}
Abstrak: Nyeri merupakan perasaan emosional dan sensoris yang menimbulkan rasa tidak nyaman, berhubungan dengan (ancaman) jaringan yang rusak. Analgetika merupakan suatu zat yang mengurangi rasa nyeri tanpa membuat pingsan atau hilang kesadaran (perbedaan dengan anestetika umum). Hewan yang digunakan sebagai hewan coba yaitu mencit (Mus musculus). Tujuan dari penelitian ini adalah untuk mengetahui perbandingan onset dari masing-masing konsentrasi gel boni yang diuji. Penelitian yang dilakukan berupa eksperimental dengan menggukan metode hot plate. Hasil penelitian menunjukkan bahwa tidak ditemukan onset pada gel boni dengan konsentrasi $0.25 \%$ karena kurva masih menaik. Onset yang diperoleh pada gel boni dengan konsentrasi $0.5 \%$ yaitu terjadi pada menit ke 90 dimana area di bawah kurva yaitu 4248 yang menunjukan persen aktivitas yang dimiliki. Onset yang diperoleh pada gel boni dengan konsentrasi $0.75 \%$ yaitu terjadi pada menit ke 90 dimana area di bawah kurva yaitu 5112 yang menunjukan persen aktivitas yang dimiliki. Semakin besar konsentrasi yang diberikan maka efek analgesik yang timbul akan semakin besar. Berdasarkan penelitian tersebut maka diperoleh data yang tedistribusi normal dan homogen serta memiliki hasil uji ANOVA one-way dengan nilai $\mathrm{P}>0.05$ yang berarti tidak ada perbedaan bermaknan anatara ketiga konsentrasi terhadap kontrol positif. Dari ketiga konsentrasi tersebut yang paling efektif memberikan efek analgesik yaitu konsentrasi $0.75 \%$.

Kata Kunci: analgesik, gel Boni, nyeri
\end{abstract}

Abstract: Pain is an emotional and sensory feeling that causes discomfort, associated with (threat) the damaged tissue. Analgesics are substances that reduce pain without causing fainting or loss of consciousness (in contrast to general anesthetics). The animal used as experimental animal is mice (Mus musculus). The purpose of this study was to determine the onset comparison of each tested Boni gel concentration. This research was conducted in the form of experimental using the hot plate method. The results showed that no onset was found for the Boni gel with a concentration of $0.25 \%$ because the curve was still increasing. The onset obtained on the Boni gel with a concentration of $0.5 \%$ occurred at 90 minutes where the area under the curve was 4248 , which shows the percentage of activity owned. The onset obtained on the Boni gel with a concentration of $0.75 \%$ occurred at 90 minutes where the area under the curve was 5112 which shows the percentage of activity that is owned. The greater the concentration given, the greater the analgesic effect. Based on this research, data were obtained that were normally distributed and homogeneous and had one-way ANOVA test results with a P value $>0.05$, which means that there was no meaningful difference between the three concentrations of the positive control. Of the three concentrations, the most effective was a concentration of $0.75 \%$.

Keywords: analgesic, Boni gel, pain

\section{PENDAHULUAN}

Nyeri merupakan kerusakan jaringan yang terjadi baik secara potensial maupun actual yang dialami makhluk hidup sehingga memeberikan rasa tidak nyaman dan tidak menyenangkan. Nyeri bisa datang atau timbul tanpa adanya sakit atau tanpa adanya hubungan dengan pusat atau sumber yang teridentifikasi. Rasa nyeri didasari oleh proses

• email korespondensi: erikajayantini12@gmail.com 
multipel yaitu nosisepsi, perubahan fenotif sensitisasi sentral, sensitisasi perifer, eksitabilitas ektopik, penurunan inhibisi, dan reorganisasi struktural. Terdapat empat proses nyeri, yaitu : transduction, transmission, modulation, dan perception (Tjay dan Rahardja, 2007).

Analgetika dalam farmakologis digunakan sebagai obat nyeri. Analgetika adalah suatu zat yang mampu memberikan penurunan rasa nyeri tanpa membuat pingsan atau menghilangkan kesadaran. Analgetik dibagi menjadi dua kelompok yaitu analgetik narkotika dan analgetik perifer (non-narkotika) (Tjay dan Rahardja, 2007). Pengujian obatan analgetika umumnya dilakukan uji klinik dan praklinik. Uji praklinik dilakukan dengan hewan uji yang telah memenuhi kriteria dan dapat menggambarkan tujuan (Malole dan Pramono, 1989).

Tujuan dalam percobaan hewan untuk memperoleh defined laboratory animals atau sehingga sifat genotipe, efek maternal, dan efek lingkungan terhadap fenotipe menjadi konstan sehingga penelitian bersifat reproducible. Dengan demikian dilakukan adaptasi hewan untuk menjamin keadaan hewan tetap stabil.

Metode hot plate merupakan suatu metode dengan meletakkan hewan uji pada hot plate yang dipanaskan pada suhu tertentu. Hewan bereaksi dengan perilaku lompat, jilat kaki, dan gemetar pada kaki, selanjutnya dikenal dengan metode hot plate. Uji coba ini cocok untuk mendeteksi aktivitas obat analgetik yang diberikan secara topikal (Mishra et al, 2011). Cara kerja dari metode ini yaitu dengan cara melakukan pengamatan frekuensi gerakan melompat, jilat kaki dan gemetar pada kaki hewan uji pada kelompok hewan yang diberikan uji dibandingkan dengan frekuensi gerakan melompat, jilat kaki dan gemetar pada kaki hewan uji pada masing-masing kelompok yang diberikan standar (obat yang sudah teruji efek analgetiknya) dan placebo (kontrol). Adanya penurunan frekuensi gerakan melompat, jilat kaki dan gemetar pada kaki hewan uji karena suatu senyawa yang memiliki efek analgetik menggambarkan kemampuan senyawa tersebut dalam meningkatkan ambang rasa nyeri (Cahyaningsih dkk, 2019).

\section{METODE PENELITIAN}

Tempat dan Waktu. Penelitian ini dilakukan di Laboratorium Penelitian Hewan, Program Studi Farmasi, Fakultas Matematika dan IImu Pengetahuan Alam, Universitas Udayana. Waktu pelaksanaan dilakukan pada Oktober hingga November 2019.

\section{Alat dan Bahan}

Peralatan yang digunakan untuk penelitian ini adalah timbangan analitik (Adam Equipment

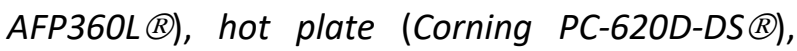
vaccum rotatory evaporator (Eyela () ), gelas beker (Pyrex $\AA$ ), sendok tanduk, kertas perkamen, spidol, gunting dan sopwatch.

Bahan yang digunakan dalam penelitian ini adalah gel bulung boni, gel basis, gel voltaren.

Rancangan Percobaan. Penelitian ini bersifat eksperimental murni dimana dilakukan perlakuan terhadap subjek uji dan bersifat eksploratif.

\section{Pelaksanaan Penelitian \\ Persiapan Bahan Uji}

Bahan yang digunakan dalam penelitian ini adalah rumput laut boni (Caulerpa sp.). Rumput laut dibersihkan dengan air bersih kemudian diangin-anginkan dan dihaluskan dan diperoleh serbuk kering. Serbuk kering rumput laut boni dimaserasi dengan etanol 70\%, kemudian disaring. Maserat yang diperoleh diuapkan dengan vaccum rotatory evaporator. Kemudian dibuat gel dengan konsentrasi $0,25 \%$; $0,5 \%$; dan $0,75 \%$ dengan formula basis NaEDTA 0,1\%; Gliserin 2\%; Propilenglikol 2\%; Optihen 1\%; Lubra gel 39\%; dan Aquadest ad $100 \%$.

\section{Pengujian Aktivitas Analgetik}

Pengujian aktivitas analgetik gel boni (Caulerpa sp.) dilakukan terhadap enam ekor mencit jantan Mus musculus dengan kriteria berumur 35-60 hari, berat badan 18-35 gram, sehat dan tidak stress (aktivitas normal) yang dibagi 
menjadi empat perlakuan. Sebelum perlakuan, hewan uji dilakukan pengadaptasian di kandangnya selama 7 hari. Kemudian dilakukan penimbangan berat badan, pengukuran $\mathrm{pH}$ dan jumlah urin, dan aktivitas mencit. Pada hari pengujian, masing-masing hewan uji diberikan perlakuan sesuai dengan kelompoknya. Berikut merupakan tabel perlakuan hewan uji taip kelompok:

Tabel 1. Perlakuan kelompok uji

\begin{tabular}{cl}
\hline Kelompok Uji & \multicolumn{1}{c}{ Perlakuan } \\
\hline I & $\begin{array}{l}\text { Kaki mencit dioleskan dengan gel } \\
\text { basis (Kontrol negatif) }\end{array}$ \\
\hline II & $\begin{array}{l}\text { Kaki mencit dioleskan dengan gel } \\
\text { voltaren (Kontrol positif) }\end{array}$ \\
\hline III & $\begin{array}{l}\text { Kaki mencit tidak dioleskan gel } \\
\text { apapun (Kelompok normal) }\end{array}$ \\
\hline IV & $\begin{array}{l}\text { Kaki mencit dioleskan dengan gel } \\
\text { boni (Kelompok perlakuan) }\end{array}$ \\
\hline
\end{tabular}

Setelah 1 menit pemberian bahan uji, tiap mencit pada kelompok I, II, II, dan IV selanjutnya diletakan di atas hot plate dengan suhu $50^{\circ} \mathrm{C}$. Waktu yang terlewat antara penempatan hewan di piring panas dan adanya perilaku menjilati telapak kaki, gemetar, atau melompat dari permukaan dicatat sebagai respon latensi dalam hitungan detik. Kemudian diukur waktu reaksi dari perilaku pertama yang ditimbulkan dimana respon yang diamati adalah menjilati telapak kaki. Pengukuran dilakukan setiap 30 menit selama 180 menit dengan waktu cut-off untuk latensi plat panas ditetapkan pada 15 detik. Selanjutnya dilakukan perhitungan aktivitas analgesik menggunakan rumus berikut:

$$
\% \text { Aktivitas Analgesik }=\frac{\mathrm{T}-\mathrm{K}}{\mathrm{C}-\mathrm{K}} \times 100 \%
$$

Keterangan :

$\mathrm{T}=$ Waktu respon setelah diberi gel boni

$\mathrm{K}=$ Waktu respon kelompok kontrol negatif

$\mathrm{C}=$ Waktu cut off (15 detik)

\section{Analisis Data}

Data hasil pengamatan dibuat dalam bentuk tabel dan analisis statistic uji one way ANOVA. Data \% aktivitas analgesik terhadap waktu dilakukan uji Shapiro Wilk untuk mengetahui distribusi data normal atau tidak. Kemudaian dilakukan uji Levene test untuk mengetahui homogenitas data. Setelah data terdistribusi normal dan homogen maka dilakukan analisis varian Oneway ANOVA dengan taraf kepercayaan 95\% dan uji LSD (Least Significant Difference). Analisis data dikerjakan dengan aplikasi SPSS.

\section{HASIL DAN PEMBAHASAN}

Penandaan mencit dilakukan sebelum penimbangan untuk memastikan kesesuaian antara mencit dengan bobotnya sehingga mempermudah dalam pencatatan bobot mencit dan meminimalisir terjadinya kesalahan.

Dari hasil penimbangan bobot mencit, diperoleh nilai RSD saat pra perlakuan yaitu sebesar $3.7075 \%$, nilai RSD saat perlakuan pada minggu pertama sebesar $8.6913 \%$, nilai RSD saat perlakuan pada minggu kedua dan ketiga yaitu $5.0359 \%$, dimana dari nilai RSD yang didapat menandakan bahwa variasi bobot mencit tidak menyimpang. Kemudian mencit dibagi menjadi 4 kelompok, yakni 3 ekor mencit sebagai kelompok uji, 1 ekor sebagai kelompok kontrol positif, 1 ekor sebagai kontrol negatif dan 1 ekor tanpa perlakuan (normal).

Setiap mencit diberikan dosis sebanyak $100 \mathrm{mg} / \mathrm{kaki}$ mencit. Sampel dioleskan pada telapak kaki hewan uji. Setelah didiamkan selama 1 menit, mencit diletakkan diatas hotplate dengan suhu $50^{\circ} \mathrm{C}$ selama maksimal 15 detik. Apabila sebelum 15 detik, mencit sudah menunjukkan adanya respon nyeri seperti menjilat kaki, melompat, atau bergetar, maka pengamatannya dihentikan. Mekanisme nyeri pada uji ini adalah melalui panas yang ditimbulkan pada hot plate akan direspon oleh reseptor nyeri (nosiseptor) di dalam kulit. Pengamatan respon hewan uji terhadap stimulasi panas dilakukan selama 2 jam dengan interval 30 menit.

Onset yang didapatkan pada penelitian kali ini yaitu; pada dosis gel boni 0,25\% tidak ditemukan onset karena kurva masih menaik. Luas Area di bawah kurva yaitu 3250 yang menunjukkan persen aktivitas yang dimiliki. Pada dosis gel boni 0,5\% onset pada menit ke-90. Luas area di bawah kurva kurva yaitu 4248 yang menunjukan persen aktivitas 
yang dimiliki. Dan Pada dosis gel boni $0,75 \%$ onset pada menit ke 90. Luas Area di bawah kurva yaitu 5112 yang menunjukkan persen aktivitas yang dimiliki.

Tabel 2. Data Aktivitas Analgesik Gel Boni

\begin{tabular}{cccccc}
\hline \multirow{2}{*}{ Perlakuan } & \multicolumn{5}{c}{ Waktu Aktivitas Analgesik (Menit) } \\
\cline { 2 - 6 } & 0 & 30 & 60 & 90 & 120 \\
\hline $\begin{array}{c}\text { Kontrol } \\
\text { Negatif }\end{array}$ & 1.45 & 1.89 & 1.38 & 4.69 & 10.30 \\
\hline $\begin{array}{c}\text { Kontrol } \\
\text { Posistif }\end{array}$ & 1.77 & 2.08 & 8.10 & 15 & 15 \\
\hline $\begin{array}{c}\text { Konsentrasi } \\
\text { gel 0.25\% }\end{array}$ & 2.00 & 2.01 & 3.43 & 7.34 & 12.98 \\
\hline $\begin{array}{c}\text { Konsentrasi } \\
\text { gel 0.5\% }\end{array}$ & 2.22 & 5.22 & 7.42 & 9.58 & 6.23 \\
\hline $\begin{array}{c}\text { Konsentrasi } \\
\text { gel 0.75\% }\end{array}$ & 3.49 & 6.23 & 10.63 & 14.88 & 7.14 \\
\hline
\end{tabular}

Berdasarkan hasil percobaan dari masingmasing dosis maka dapat ditetapkan bahwa konsentrasi gel boni $0.75 \%$ mampu memiliki aktivitas analgesik yang paling tinggi dibandingkan dengan dosis gel boni $0.25 \%$ dan dosis gel boni $0.5 \%$. Disebabkan karena gel boni dengan $0.75 \%$ adalah dosis maksimum yang dapat menimbulkan efek aktivitas analgesik yang paling tinggi. Hal ini menunjukkan bahwa kekuatan onset (obat mulai bekerja) dengan dosis $0.75 \%$ ini gel boni dapat bekerja secara maksimal dalam menimbulkan aktivitas analgesik tersebut. Senyawa yang diduga memberikan aktivitas analgesik pada Caulerpa sp. adalah kartenoid. Terdapat Sembilan jenis karotenoid, namun yang memiliki efek sebagai analgesik yaitu astaxanthin (Tosiyah dkk., 2016).

Berdasarkan hasil yang diperoleh dari tiga kali percobaan dengan memberikan konsentrasi yang berbeda-beda setiap kali percobaan, dimana dari ketiga konsentrasi teserbut yang paling efektif memberikan efek analgesik yaitu konsentrasi $0.75 \%$.

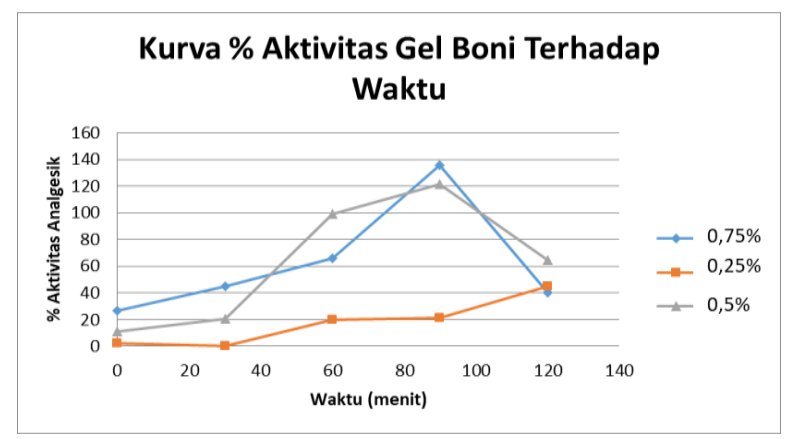

Gambar 1. \% Aktivitas Gel Boni Terhadap Waktu
Untuk memberikan hasil yang sesuai maka dilakukan analisis data menggunakan ANOVA one way. Pada uji normalitas dan homogenitas diperoleh data yang terdistribusi normal dan homogen. Berdasrakan uji LSD nilai aktivitas analgesik gel boni dengan konsentrasi $0.25 \% ; 0.5 \%$; $0.75 \%$; basis gel tidak berbeda bermakna terhadap kontrol positif (gel voltaren) atau $\mathrm{P}>0.05$ sehingga dapat diasumsikan konsentrasi gel memiliki efek analgesik yang relatif sama.

$\mathrm{ED}_{50}$ adalah dosis yang secara farmakologi menimbulkan efek (efektif) pada $50 \%$ populasi yang terpapar obat (Simon et al, 2017). ED 50 dapat dihitung dengan cara membuat kurva hubungan antara dosis dan \% akivitas. Berdasarkan hasil percobaan, diperoleh nilai $E D_{50}$ dari ketiga konsentrasi gel boni yang digunakan yaitu sebesar 0.6833 yang menunjukkan bahwa pada konsentrasi tersebut gel boni dapat memberikan efek terapi yang efektif.

\section{SIMPULAN}

Onset yang dihasilkan oleh gel boni dengan konsentrasi $0.5 \%$ dan $0.75 \%$ adalah 90 menit. Namun tidak ditemukan nilai onset dari konsentrasi gel boni $0.25 \%$. Dari ketiga konsentrasi tesebut yang paling efektif memberikan efek analgesik yaitu konsentrasi $0.75 \%$. Semakin besar konsetrasi gel boni yang diberikan maka efek analgesik yang timbul akan semakin besar pula. Nilai $E_{50}$ dari ketiga konsentrasi gel boni yang digunakan yaitu sebesar 0.6833 yang menunjukkan bahwa pada konsentrasi tersebut gel boni dapat memberikan efek terapi yang efektif.

\section{DAFTAR PUSTAKA}

Cahyaningsih, N.K., D.A. Satriawati, I.G.P.A.P. Wicaksana, S. Yulita, N.N.F. Sukarmini, N.K.W. Astuti, A. A. G. R. Y.-P. (2019). Uji Aktivitas Analgesik Ekstrak Etanol Daun Jeruk Limau (Citrus amblycarpa (Haskk.) Ocshe) pada Mencit Jantan Galur Balb/C dengan Metode Hot Plate. Jurnal Farmasi Udayana, 8(1), 36-43. 
Malole, M.M.B, P. (1989). Penggunaan Hewan Hewan Percobaan Laboratorium. DitJen Pendidikan Tinggi Pusat Antar Universitas Bioteknologi.

Mishra, D., G. Ghosh, P. S. Kumar, and P. K. P. (2011). An Experimental Study Of Analgesic Activity Of Selective Cox-2 Inhibitor With Conventional NSAID's. Asian Journal of Pharmaceutical and Clinical Research, 4(11), 78-81.

Simon D., H. Stampher, and J. H. M. (2017). When less is more-efficacy with less toxicy, at the ED50. British Journal of Clinical Pharmacology, 83(1), 1365-1368.
Tjay, T. H., Rahardja, K. (2007). Obat-Obat Penting Khasiat, Penggunaan dan Efek-Efek Sampingnya (Edisi Keen). PT. Elex Media Komputindo.

Tosiyah., K. S. Marhaeni., A. P. (2016). Kemampuan Ekstrak Rumput Laut Bulung Boni (Caulerpa Sp.) Dalam Menghambat Pertumbuhan Aspergillus Flavus Pada Biji Jagung. Jurnal Plumula, 5(2), 168-178. 